\title{
肉牛肥育一水稲作複合システムにおける農家レベルの 栄養素収支と内部循環の関係
}

\author{
田端祐介・大石風人・熊谷 元・広岡博之 \\ 京都大学大学院農学研究科, 京都市左京区 606-8502
}

(2007. 8. 17 受付, 2007. 11. 26 受理)

\begin{abstract}
要 約 本研究では, 肉牛肥育一水稲作複合システムにおける栄養素収支と内部循環の関係について 検討を試みた。事例農家における窒素, リンフローの調査デー夕を用い，肉牛肥育一水稲作複合システ ムにおける栄養素フローモデルを構築し, 肉牛飼養密度の増減に伴う窒素とリンの収支および循環を示 した。その結果, システムの栄養素利用効率（搬出量/搬入量）に影響を及ぼす要因としては, 肉牛飼養 密度, 家畜生産と作物生産の生産物/搬入比, 堆肥搬出の影響が大きく, 内部循環はこれらの要因より影 響が小さいことが示唆された。また，事例農家のシステムでは，内部循環は，窒素とリンのロス量（搬 入量一搬出量）を低減させるが，システム全体の利用効率を窒素では増加，リンでは逆にやや減少させ ることが示された。さらに, 肉牛飼養密度の增減に伴う内部循環とシステム全体の窒素とリンの収支の 関係を示した結果, 内部循環と栄養素収支との関係性には一定の傾向がみられなかった.
\end{abstract}

日本畜産学会報 79 (1), 79-88, 2008

窒素やリンなどの栄養素は，家畜生産と作物生産にお いて必要不可欠な元素であるが，その一方で，水系や大 気中への散逸量が過剩になれば，環境污染に寄与する危 険性があると指摘される（押田ら 2002）。家畜と作物を 統合した家畜一作物複合システムでは，これらの栄養素 が家畜一作物間において循環利用されることにより，資 源の有効利用に加えて, システム外に散逸する栄養素量 を低減させることが可能と予想される。従って, 家畜一 作物複合システムは，環境保全や資源の有効利用の観点 から重要と推察される。

我が国では，伝統的に水稲作が盛んであることから， 家畜一作物複合システムの一形態として, 水稲を含む家 畜一作物複合システムが提案できると考えられる．著者 らは，これまで肉牛肥育一水稲作複合システムにおける 栄養素循環の実態把握を事例農家を対象に行い, その結 果, 肉牛生産一水稲作複合システムにおける窒素とリン の収支に加えて, システム内部の窒素とリンの循環量を 明らかにした（田端ら 2005，2006a，b).しかしながら, これまでの報告では，システム全体の窒素とリンの収支 と，内部循環の関係については，十分に検討されていな かった.

システム全体の栄養素収支と内部循環の関係について は, 解析法が未確立であるとともに, 内部循環を定量的 に把握した報告例が少ないことから，ほとんど明らかに されていないのが現状である. 著者らは, 解析手法の一
つとして，報告事例のデー夕を基にして栄養素つローモ デルを作成し, シミュレーションを行う方法に注目して いる. この手法は, 同一のシステムにおいて様々な状況 での栄養素フローの結果が算出できるため, システム全 体の栄養素収支と内部循環の関係を検討するうえで有用 と推察される. そこで, 本研究では, 肉牛肥育一水稲作 複合システムにおいて, 事例農家のデー夕に基づいたシ ミュレーションを行い，農家レベルのシステムの栄養素 収支と系内の栄養素循環亡の関係を解析することを目的 とした。解析は肉牛飼養密度（土地あたりの家畜飼養頭 数）の変化を軸とし，1）農家の栄養素収支の変化，2） 家畜-作物間の栄養素循環の有無がシステム全体の栄養 素収支に及ぼす影響, 3) 栄養素循環とシステム全体の栄 養素収支との関係について行った。

\section{材料および方法}

\section{1. 対象農家}

システムの事例として，田端ら（2005，2006a）が調査 を行った, 京都府下の肉牛肥育と水稲作の複合経営農家 を対象とした。農家の概況は表 1 に示す通りである。こ の農家では, 黒毛和種去勢牛が 10 頭飼養され, 購入から 出荷に至るまで 2 年肥育された。また，耕地面積は 7.0 ha で，そのうち 5.9 ha が水田として利用され，残り 1.1 ha は休耕田であった。水稲作への施肥は, 化学肥料単 独, もしくは化学肥料亡堆肥の併用であった. 本農家の

連絡者：田端祐介（fax：075-753-6365, e-mail：ytabata@kais.kyoto-u.ac.jp） 
デー夕を用いた理由は，この農家の土地利用が水田を主 とすることから, 水稲作と肉牛との関係を解析するに適 すると考えられたことに加え, 調査農家では, 化学肥料 単独の施肥と堆肥と化学肥料の併用が行われており, 堆 肥を化学肥料で代替した場合の窒素とリンの施肥量が求 められたためである.

調査農家における栄養素フローの概要を図 1 に示す。 まず, システムの構造からみると, 肉牛肥育一水稲作複 合システムは, 肉牛肥育 $\left(H_{1}\right)$, 堆肥 $\left(H_{2}\right)$, 水稲生産 $\left(H_{3}\right)$, 作物/副産物部門 $\left(\mathrm{H}_{4}\right)$ の 4 部門加構成されている. 次 に，窒素とリンのフローをみると，矢印であらわされる フローは, システム内外の経路と, 部門間の経路に大別 される. システムへの投入 (Input) の経路は, 肉牛肥育 および水稲生産部門への搬入 (Import) であり, 他方, シ ステム外部への産出 (Output) は, 肉牛肥育部門亡作物/

Table 1 Characteristics of surveyed farms

\begin{tabular}{lc}
\hline \hline Beef fattening & 10 \\
\hline Number of fattening steers (head) & $200 \pm 15^{\mathrm{a}}$ \\
Weight of purchased calves $(\mathrm{kg})$ & $678 \pm 19^{\mathrm{a}}$ \\
Weight of sold steers $(\mathrm{kg})$ & 730 \\
Period of fattening (day) & 7.0 \\
Cultivation & 5.9 \\
\hline Total land size (ha) & 1.1 \\
Paddy field (ha) & 31 \\
No-cultivated area (ha) & \\
Total yield of brown rice $(\mathrm{t})$ &
\end{tabular}

a : Mean weight \pm standard deviation $(n=5)$.
副産物部門からの搬出（Export）とロス（Loss）であっ た.ここで，ロスは，各部門への般入量から搬出量を差 し引いて求めたものであり，環境へ散冕した元素量の指 標となるものである.さらに, 系内の窒素とリンのフ ローをみると, 肉牛肥育, 堆肥, 水稲生産, 作物/副産物 の部門を順に流れており，システム内で循環が成立して いる.ここで，水稲生産部門には 1.1 ha の休耕田も含ま れており，そのため，水稲生産部門から肉牛肥育部門へ のフローには水稲副産物の他にも野草が含まれている.

野草は休耕田や畦半から採取されたもので, 肉牛の飼料 として利用された.

調査農家におけるフロー量を項目毎に示したのが表 2 である. 肉牛については, 肉牛は導入後 2 年間の肥育を へて出荷されるため, 肉牛の窒素量とリン量は単年度あ たり半頭の換算となっている. また, 肉牛生産の生産物/ 搬入比 [出荷牛/(飼料十敷料)] は, 窒素とリンがそれぞ れ $0.08,0.10$ であり, 他方, 水稲生産における生産物/搬 入比 [(出荷精米十籾款十米奻種子)/(化学肥料十培 土十種子)]は，窒素とリンでそれぞれ 0.95，0.23であっ た.さらにこの農家の施肥方法は，化学肥料の一部を 堆肥で代替する方法であるが, その堆肥を化学肥料で代 替する比率（化学肥料/堆肥比）は, 窒素で 0.14 , リンで 0.16 であった.

2. シミュレーション

1）肉牛飼養密度の変化に伴うシステムの栄養素収支

ここでは，調査農家の状況を基にした肉牛一水稲間の 循環系を活用するシステム (以下, MIX システムと定義) において, 肉牛飼養密度を変化させるシミュレーション を行った.ここで，肉牛飼養密度を軸としたのは，シス

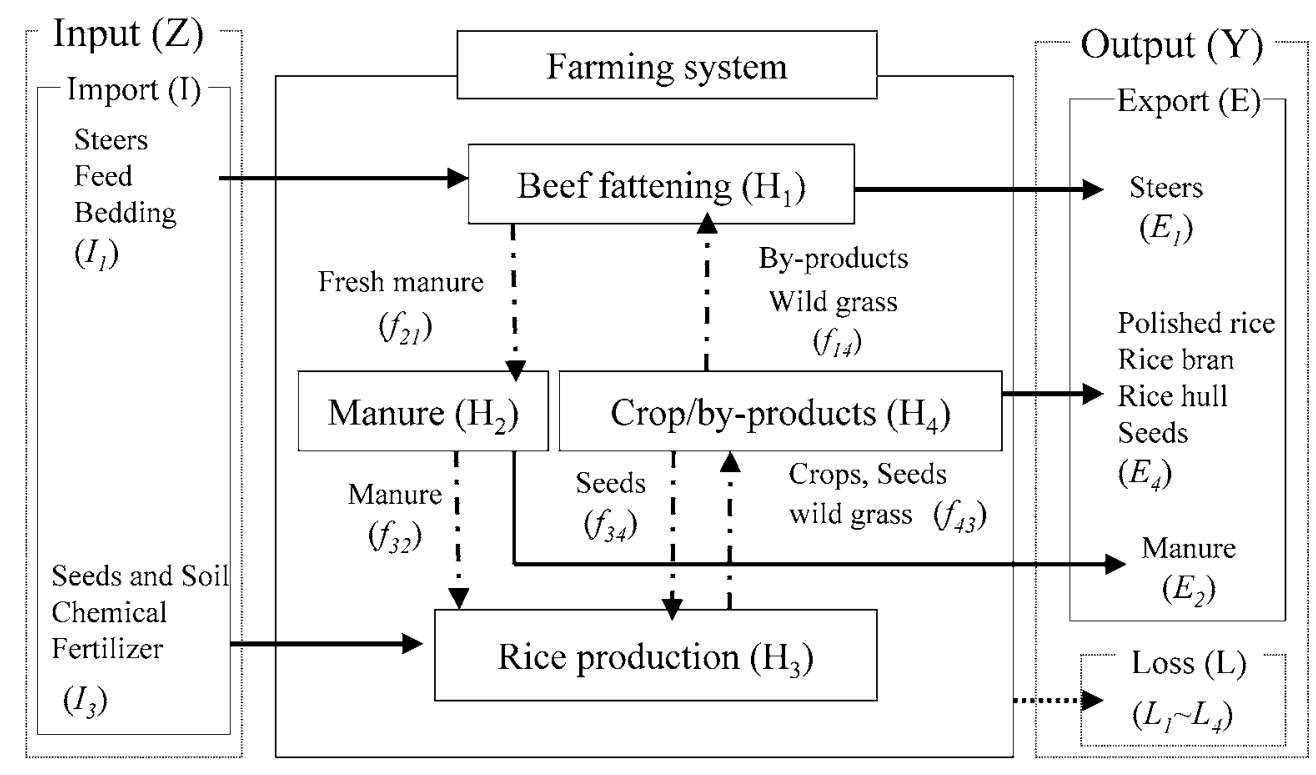

Figure 1 Schematic nutrient flows in a mixed farming system for beef fattening and rice production $\longrightarrow$ : Import and export $\rightarrow$... Cycling $\rightarrow \cdots \cdots$ : Losses 
Table 2 Coefficients of nitrogen and phosphorus flows in the surveyed farm

\begin{tabular}{|c|c|c|c|c|}
\hline \multirow[b]{2}{*}{ Items } & \multirow[b]{2}{*}{ Unit } & \multirow[b]{2}{*}{ Flow $^{\mathrm{a}}$} & \multicolumn{2}{|c|}{ Values } \\
\hline & & & Nitrogen & Phosphorus \\
\hline \multicolumn{5}{|l|}{ Animals } \\
\hline Purchased steer ${ }^{\mathrm{b}}(\mathrm{A})$ & $\mathrm{kg} /$ year/steer & $I_{1}$ & 2.72 & 0.65 \\
\hline Sold steer ${ }^{\mathrm{b}}$ & $\mathrm{kg} /$ year/steer & $E_{1}$ & 7.21 & 1.82 \\
\hline \multicolumn{5}{|l|}{ Feed and bedding (B) } \\
\hline Purchased feed & $\mathrm{kg} /$ year/steer & $E_{1}$ & 70.17 & 12.86 \\
\hline Rice bran & $\mathrm{kg} /$ year/steer & $f_{14}$ & 2.25 & 1.88 \\
\hline Rice hull & $\mathrm{kg} /$ year/steer & $f_{14}$ & 2.04 & 0.28 \\
\hline Rice straw & $\mathrm{kg} /$ year/steer & $f_{14}$ & 9.18 & 1.64 \\
\hline Wild grass & $\mathrm{kg} /$ year/steer & $f_{14}$ & 6.77 & 2.02 \\
\hline Fresh manure & $\mathrm{kg} /$ year/steer & $f_{21}$ & 43.78 & 17.30 \\
\hline Ratio of product/import (A/B) & & & 0.08 & 0.10 \\
\hline \multicolumn{5}{|l|}{ Manure } \\
\hline $\begin{array}{l}\text { The ratio of remain during } \\
\text { composting }\end{array}$ & & & 0.78 & 0.96 \\
\hline \multicolumn{5}{|l|}{ Crops } \\
\hline Seeds and soils (C) & $\mathrm{kg} /$ year/farm & $I_{3}$ & 10.6 & 2.5 \\
\hline Yield & & & & 67.5 \\
\hline Sold polished rice (D) & $\mathrm{kg} /$ year/farm & $E_{4}$ & 327.4 & 18.8 \\
\hline Rice bran (E) & $\mathrm{kg} /$ year/farm & $f_{43}$ & 22.5 & 3.3 \\
\hline Rice hull (F) & $\mathrm{kg} /$ year/farm & $f_{43}$ & 22.3 & 39.3 \\
\hline Rice straw & $\mathrm{kg} /$ year/farm & $f_{43}$ & 220.3 & 22.3 \\
\hline Wild grass & $\mathrm{kg} /$ year/farm & $f_{43}$ & 74.1 & \\
\hline Rice seeds ${ }^{c}$ & $\mathrm{~kg} /$ year/farm & $f_{43}$ & 26.4 & 6.6 \\
\hline Chemical fertilizer $(G)^{d}$ & $\mathrm{~kg} /$ year/farm & $l_{3}$ & 409.5 & 410.7 \\
\hline Chemical fertilizer/manure & & & 0.14 & 0.16 \\
\hline Ratio of product/import $[(\mathrm{D}+\mathrm{E}$ & $F+H) /(C+G)]$ & & 0.95 & 0.23 \\
\hline
\end{tabular}

a : Coefficients were included in symbolized flows.

$b$ : Nitrogen and phosphorus contents of steers per year were calculated as half amount because fattening periods was two years.

$c$ : Rice seed were sold $(H)(N: 24.8, P: 6.1)$ and used for rice production ( $N: 1.6, P: 0.5)$.

$d$ : The amount of chemical fertilizer was calculated in the case of sole fertilizer.

テム全体の窒素とリンの収支の変化を, 肉牛飼養密度の 観点から明らかにするためである. 肉牛飼養密度の変化 に伴うMIX システムにおける作物/副産物利用および堆 肥利用のシナリオは表 3 に示す通りである。堆肥は，堆 肥量が水田への投入可能量以下であれば全て水田に還元 し, 肉牛飼養密度の増加に伴い堆肥量が投入可能量を超 過すると系内のロスもしくは系外への搬出とした。次に， 稲わらは, 肉牛飼養への必要量が自給量以下であれば必 要量のすべてが自給され, 飼養頭数の増加に伴い必要量 が自給量を超過すれば，不足する稲わらが系内に搬入さ

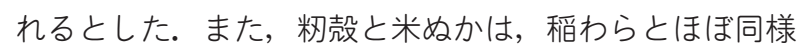
であるが, 余剩量 (自給量一必要量) が系外に搬出され る点が異なる. 野草は, 肉牛飼養に必要な野草が採取さ
れるが, 飼養頭数の増加に伴い, 必要量が自給量を超過 すると系外から般入されるとした. MIX システムのシナ リオにおける，投入可能量や自給量の値 (Constraints) と窒素とリン量の算出式 (Equations) は表 4 に示す通り である.

検討はシステム全体における栄養素の搬入量, 搬出 量, ロスおよび利用効率 (Use efficiency; 般出量/搬入 量）について行った。ここで，利用効率は栄養素の効率 的利用度を示す指標であり，1に近づくほどシステム内 で栄養素が効率よく利用されたことを示す。

2）内部循環がシステム全体の栄養素収支に及ぼす影響 システム内部における栄養素循環がシステム全体の栄 養素収支へどのような影響を及ばすかは，同じシステム 
田端・大石・熊谷・広岡

Table 3 Assumed scenarios for each item in MIX systems

\begin{tabular}{|c|c|}
\hline Items & Scenarios \\
\hline \multirow[t]{2}{*}{ Manure } & $\begin{array}{l}\text { - When excreted manure } \leqq \text { available capacity } \\
\text { then all manure is spread on farmer's paddy field }\end{array}$ \\
\hline & $\begin{array}{l}\text { - When excreted manure >available capacity } \\
\text { then exceed manure is lost into environment or exported }\end{array}$ \\
\hline \multirow[t]{2}{*}{ Rice bran } & $\begin{array}{l}\text { - When home made rice bran } \geqq \text { requirement as feed } \\
\text { then rice bran is fed to beef steers and surplus is exported }\end{array}$ \\
\hline & $\begin{array}{l}\text { - When home made rice bran< <equirement as feed } \\
\text { then all home made rice bran is fed to beef steers } \\
\text { and deficit one is imported }\end{array}$ \\
\hline \multirow[t]{2}{*}{ Rice hull } & $\begin{array}{l}\text { - When home made rice hull } \geqq \text { requirement as feed and bedding } \\
\text { then rice hull is used for beef steers and surplus is exported }\end{array}$ \\
\hline & $\begin{array}{l}\text { - When home made rice hull < requirement as feed } \\
\text { then all home made rice hull is used to beef steers } \\
\text { and deficit one is imported }\end{array}$ \\
\hline \multirow[t]{2}{*}{ Rice straw } & $\begin{array}{l}\text { - When home made rice straw } \geqq \text { requirement as feed } \\
\text { then home made rice straw is fed to beef steers }\end{array}$ \\
\hline & $\begin{array}{l}\text { - When home made rice straw }<\text { requirement as feed } \\
\text { then all home made rice straw is fed to beef steers } \\
\text { and deficit one is imported }\end{array}$ \\
\hline \multirow[t]{2}{*}{ Wild grass } & $\begin{array}{l}\text { - When home made wild grass } \geqq \text { requirement as feed } \\
\text { then home made wild grass is fed to beef steers }\end{array}$ \\
\hline & $\begin{array}{l}\text { - When home made wild grass < requirement as feed } \\
\text { then all home made wild grass is fed to beef steers } \\
\text { and deficit one is imported }\end{array}$ \\
\hline
\end{tabular}

Table 4 Constrains and equations of nitrogen and phosphorus utilization in MIX systems with the changes in number of steers

\begin{tabular}{|c|c|c|c|c|}
\hline \multirow[b]{2}{*}{ Item } & \multicolumn{2}{|r|}{ Nitrogen } & \multicolumn{2}{|r|}{ Phosphorus } \\
\hline & Constraints & Equations & Constraints & Equations \\
\hline \multirow[t]{2}{*}{ Manure } & $<605.6 \mathrm{~kg}$ & $f_{32}=34.16 \times \mathrm{n}^{\mathrm{a}}$ & $<294.3 \mathrm{~kg}$ & $f_{32}=16.58 \times \mathrm{n}$ \\
\hline & $\geqq 605.6 \mathrm{~kg}$ & $f_{32}=605.6, E_{2}$ or $L_{2}=34.16 \times n-605.6$ & $\geqq 294.3 \mathrm{~kg}$ & $f_{32}=294.3, E_{2}$ or $L_{2}=16.58 \times n-294.3$ \\
\hline \multirow[t]{2}{*}{ Rice straw } & $<220.3 \mathrm{~kg}$ & $f_{14}=9.18 \times n$ & $<39.3 \mathrm{~kg}$ & $f_{14}=1.64 \times n$ \\
\hline & $\geqq 220.3 \mathrm{~kg}$ & $f_{14}=220.3, l_{1}=9.18 \times \mathrm{n}-220.3$ & $\geqq 39.3 \mathrm{~kg}$ & $f_{14}=39.3, l_{1}=1.64 \times n-39.3$ \\
\hline \multirow[t]{2}{*}{ Rice hull } & $<22.3 \mathrm{~kg}$ & $f_{14}=2.04 \times \mathrm{n}, E_{4}=22.3-2.04 \times \mathrm{n}$ & $<3.3 \mathrm{~kg}$ & $f_{14}=0.28 \times \mathrm{n}, E_{4}=3.3-0.28 \times \mathrm{n}$ \\
\hline & $\geqq 22.3 \mathrm{~kg}$ & $f_{14}=22.3, I_{1}=2.04 \times \mathrm{n}-22.3$ & $\geqq 3.3 \mathrm{~kg}$ & $f_{14}=3.3, l_{1}=0.28 \times \mathrm{n}-3.3$ \\
\hline \multirow[t]{2}{*}{ Rice bran } & $<22.5 \mathrm{~kg}$ & $f_{14}=2.25 \times \mathrm{n}, E_{4}=22.5-2.25 \times \mathrm{n}$ & $<18.8 \mathrm{~kg}$ & $f_{14}=1.88 \times \mathrm{n}, E_{4}=18.8-1.88 \times \mathrm{n}$ \\
\hline & $\geqq 22.5 \mathrm{~kg}$ & $f_{14}=22.5, l_{1}=2.25 \times n-22.5$ & $\geqq 18.8 \mathrm{~kg}$ & $f_{14}=18.8, l_{1}=1.88 \times n-18.8$ \\
\hline \multirow[t]{2}{*}{ Wild grass } & $<74.1 \mathrm{~kg}$ & $f_{14}=6.77 \times \mathrm{n}$ & $<22.3 \mathrm{~kg}$ & $f_{14}=2.02 \times n$ \\
\hline & $\geqq 74.1 \mathrm{~kg}$ & $f_{14}=74.1, l_{1}=6.77 \times \mathrm{n}-74.1$ & $\geqq 22.3 \mathrm{~kg}$ & $f_{14}=22.3, l_{1}=2.02 \times n-22.3$ \\
\hline
\end{tabular}

$a: n:$ number of steers (head).

Animal intensification was represented as the number of steers per land are (ha).

において循環の成立するシナリオと成立しないシナリオ を比較することにより把握できると考えられる。 そこ で，本解析では，すでに定義したMIX システムに対し， 栄養素循環が成立しないシステム（以下，SEPシステ ム）を仮定し，両者の比較を行った。肉牛飼養密度の変
化に伴う，SEP システムのシナリオは表 5 に示す通りで ある. SEP システムは, 肉牛と水稲間の栄養素循環がな く，自給した飼料，肥料がすべて購入されるとともに， 水稲副産物, 野草および堆肥が飼料や肥料として利用さ れないシナリオである. また，肉牛飼養密度の増加に伴 
肉牛肥育・水稲作複合の循環解析

Table 5 Assumed scenarios for each item in SEP systems

\begin{tabular}{|c|c|}
\hline Items & Scenarios \\
\hline Manure & - manure is treated as loss to environment \\
\hline \multirow[t]{2}{*}{ Rice bran } & - home made rice bran is all exported \\
\hline & - The requirement of ricre bran for feeding beef steers is imported \\
\hline \multirow[t]{2}{*}{ Rice hull } & - home made rice hull is all exported \\
\hline & - The requirement of ricre hull for feeding beef steers is imported \\
\hline \multirow[t]{2}{*}{ Rice straw } & - home made rice straw is not utilized for feeding beef steers \\
\hline & - The requirement of ricre straw for feeding beef steers is imported \\
\hline \multirow[t]{2}{*}{ Wild grass } & - Wild grass is not harvested from the farm \\
\hline & - The requirement of wild grass for feeding beef steers is imported \\
\hline
\end{tabular}

Table 6 Constrains and equations of nitrogen and phosphorus utilization in SEP systems with the changes in number of steers

\begin{tabular}{llll}
\hline \hline \multirow{2}{*}{ Item } & \multicolumn{1}{c}{ Nitrogen } & & \multicolumn{1}{c}{ Phosphorus } \\
\cline { 2 - 2 } Manure & $L_{2}=34.16 \times \mathrm{n}^{\mathrm{a}}$ & & \multicolumn{1}{c}{ Equations } \\
Rice straw & $I_{1}=9.18 \times \mathrm{n}$ & & $L_{2}=16.58 \times \mathrm{n}$ \\
Rice hull & $I_{1}=2.04 \times \mathrm{n}, E_{4}=2.04 \times \mathrm{n}$ & & $I_{1}=1.64 \times \mathrm{n}$ \\
Rice bran & $I_{1}=2.25 \times \mathrm{n}, E_{4}=2.25 \times \mathrm{n}$ & & $I_{1}=1.88 \times \mathrm{n}, E_{4}=0.28 \times \mathrm{n}$ \\
Rice bran & $I_{1}=6.77 \times \mathrm{n}$ & & $I_{1}=2.02 \times \mathrm{n}$ \\
\hline
\end{tabular}

a : $n$ : number of steers (head).

Animal intensification was represented as the number of steers per land area (ha).

う窒素量とリン量の算出値は表 6 に示す通りである. 栄養素循環の影響は影響指数 (Effect index) として, SEP システムに対する MIX システムの増減率 (\%) で表 した（式 1).

循環の影響指数 $(\%)=(\mathrm{MIX}-\mathrm{SEP}) / \mathrm{SEP} \times 100 （$ 式 1) ただし，MIXとSEPは，MIX システムと SEP システム における，栄養素口スあるいは利用効率である。

3）循環指標とシステム全体の栄養素収支の関係 本解析では，肉牛飼養密度の増加に伴う，システムの 内部循環と, システム全体の栄養素収支の変化を示し, 両者の関係について検討した。 システム内の栄養素循環 を評価する指標としては，生態学分野で物質循環を評価 するために用いられる循環指標 (Cycling index; 以下 Cl と略)を用いた(Finn 1976, 1980, 1983). 循環指標は, シ ステムにおける総フロー量 (TST ; Total system throughflow) に対する循環量（TSTc；Cycled portion of total system throughflow）で定義される（式 2). 循環指標は0 から 1 の値をとり，数値が大きいほど，投入した栄養素 のうち循環する栄養素が多いことを示す。
Table 7 Matrix description of nutrient flows

\begin{tabular}{c|cccccc}
\hline \hline & $H_{1}$ & $H_{2}$ & $H_{3}$ & $H_{4}$ & Input $\left(Z_{i}\right)$ & $\operatorname{Sum}\left(T_{i}\right)$ \\
\hline$H_{1}$ & 0 & 0 & 0 & $f_{14}$ & $Z_{1}$ & $T_{1}$ \\
$H_{2}$ & $f_{21}$ & 0 & 0 & 0 & 0 & $T_{2}$ \\
$H_{3}$ & 0 & $f_{32}$ & 0 & 0 & $Z_{3}$ & $T_{3}$ \\
$H_{4}$ & 0 & 0 & $f_{43}$ & 0 & 0 & $T_{4}$ \\
Output $\left(Y_{j}\right)$ & $y_{1}$ & $y_{2}$ & $y_{3}$ & $y_{4}$ & & \\
Sum $\left(T_{j}\right)$ & $T_{1}$ & $T_{2}$ & $T_{3}$ & $T_{4}$ & & \\
\hline
\end{tabular}

$H_{1}$ : Animal component, $H_{2}$ : Manure component, $H_{3}$ : Rice production component, $H_{4}$ : Crop/by-products component, $f_{i j}$ : nitrogen or phosphorus flow from compartment $\mathrm{H}_{\mathrm{j}}$ to compartment $\mathrm{H}_{\mathrm{i}}$

Input $\left(Z_{i}\right)=l_{i}$, Output $\left(Y_{j}\right)=E_{j}+L_{j}$.

$$
\mathrm{Cl}=\mathrm{TST} \mathrm{c} / \mathrm{TST}(0 \leqq \mathrm{Cl} \leqq 1)
$$

循環指標の算出方法はFinn（1980）に従った. システ 厶の栄養素フローは投入 $(Z)$, 内部循環 $(F)$, 産出 $(Y)$ などフロー経路により識別され，行列で表 7 のように表 記される.ここで，Tiおよび $T_{j}$ は各行および各列の総和 
であり, それぞれ $i$ 部門への投入量, $j$ 部門からの産出量 を示す. システムにおける総フロ一量 (TST) は, これら 部門への投入量の総和で算出される (式 3 ).

$$
\mathrm{TST}=\sum_{i=1}^{4} T_{i}
$$

また, システム内の循環量（TSTC）は, (式 4) から求め られる.

$$
\mathrm{TSTC}=\sum_{i=1}^{4}\left[\left\{\left(n_{i i}-1\right) / n_{i i}\right\} \times T_{i}\right]
$$

なお, $\left\{\left(n_{i i}-1\right) / n_{i i}\right\}$ は, 行列 $N$ の対角成分で, その行 列 $N$ は次の（式 5）より求められる.

$$
\mathrm{N}=[\mathrm{I}-\mathrm{Q}]^{-1}\left(\because \quad 0 \leqq q_{i j} \leqq 1\right)
$$

ここで,、は単位行列，Qは部門間のフローを各部門への 投入フロー量 $\left(T_{i}\right)$ あたりに換算した標準化行列であり, $\mathrm{Q}$ の $i$ 番目の行, $j$ 番目の列の要素は $q_{i j}$ で表されている. また, $\left(n_{i i}-1\right) / n_{i i}$ は循環効率を表し,$i$ 部門に投入された 栄養素のうち循環した栄養素の比率を示している.

検討は, 肉牛飼養密度の変化に伴う Cl の変化, および $\mathrm{Cl}$ とシステム全体の栄養素ロスと利用効率の関係につ いて行った.

\section{結果}

\section{1. 肉牛飼養密度の変化に伴う MIX システムの栄養} 素収支

肉牛飼養密度の増加に伴い, システム全体の窒素とリ ンのロス量の変化が単位によりどのように異なるかを示 すことは，ロス量が何に依存するかを明らかにするうえ で重要と考えられる. システム全体におけるロス量を単 位面積あたりおよび肉牛 1 頭あたりで示したのが，図 2 と図 3 である. 土地当たりの窒素とリンのロス量をみる と, 肉牛を飼養しない状況では, 窒素ロスよりリンロス が多いが, 肉牛の飼養頭数の増加に伴い, 窒素ロスがリ ンロスより多く増加し, その結果, 肉牛飼養密度 0.9 頭/ ha 以上で窒素ロスがリンロスを超過した（図 2).また, 肉牛 1 頭あたりの窒素とリンのロス量はどちらも減少す るが, 窒素に比ベリンが大きく減少した（図 3). した がって, 窒素とリンのロス量は, 単位により異なること が示された.

窒素とリンの利用効率について, 肉牛飼養密度との関 係を図 4 に示す。まず，余剩堆肥が系内のロスとなるシ ナリオ（窒素：，、リン：）をみると, 肉牛飼養密度の 増加に伴い窒素とリンの利用効率はどちらにおいても減 少した。肉牛 0 頭では，システム全体の利用効率は，土 壤/作物部門における作物生産の生産物/搬入比と同じ で，窒素で $0.95 ，$ リンで 0.23 であった。 また，肉牛飼養 密度を増加させるに伴い, システム全体の利用効率は減 少し, 肉牛生産部門の生産物/搬入比 (窒素: 0.08 , リン: 0.10)に近づいていった. さらに, 窒素とリンの利用効率

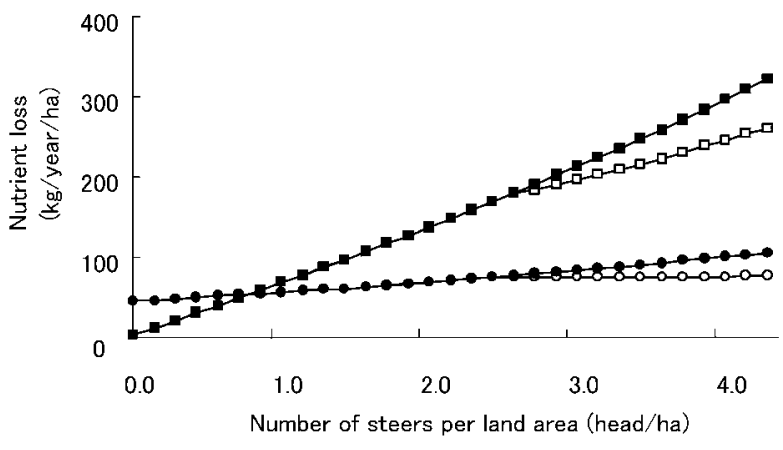

Figure 2 Nutrient loss (import-export) per land size (ha) for nitrogen and phosphorus as affected by the number of steers per land area. Nitrogen (squares) and phosphorus (circles) in the scenarios when surplus manure was regarded as loss (black) and export (white).

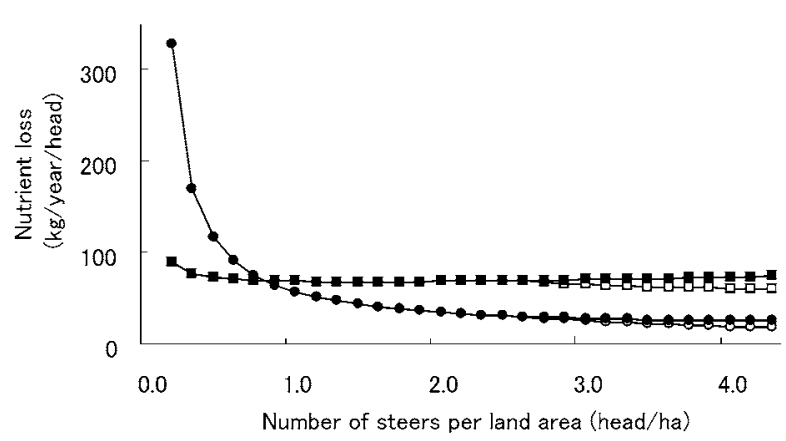

Figure 3 Nutrient loss (import-export) per beef steer (head) for nitrogen and phosphorus as affected by the number of steers per land area. Nitrogen (squares) and phosphorus (circles) in the scenarios when surplus manure was regarded as loss (black) and export (white).

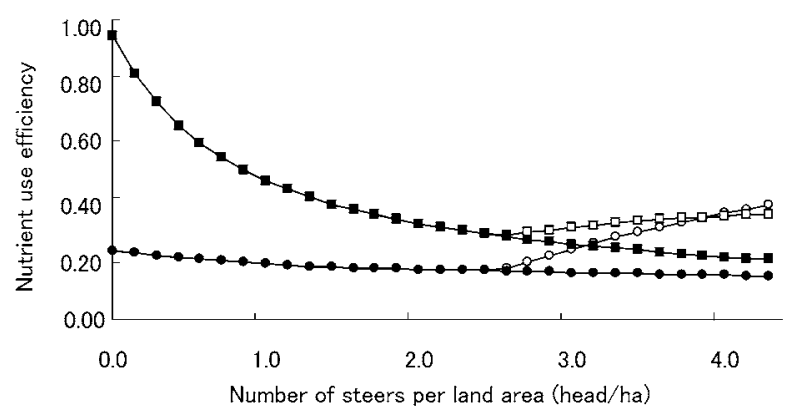

Figure 4 Nutrient use efficiency (export/import) for nitrogen and phosphorus as affected by the number of steers per land area. Nitrogen (squares) and phosphorus (circles) in the scenarios when surplus manure was regarded as loss (black) and export (white).

について，余剩堆肥をシステム外に搬出するシナリオ (窒素 : $\square$, リン：○) をみると (図 4), 2.6 頭/ha で涂 堆肥が搬出され始め, 堆肥搬出しないシナリオに比べて 
システム全体の利用効率が高まることが示された。ま た，余剩堆肥の搬出によるシステムの利用効率の増加は 窒素よりリンで大きかった。

\section{2.内部循環がシステム全体の栄養素収支に及ぼす影響}

MIX システムとSEP システムにおける, 肉牛飼養密 度の増加に伴う栄養素のロスと利用効率の変化をそれ ぞれ図 5 と図 6 に示す.まず，栄養素のロスの変化をみ ると, 肉牛飼養密度の増加に伴い両システムともに, 窒 素ロスとリンロスが増加したが, 飼養頭数あたりのロス の増加量は内部循環がないSEP システムで多かった (図 5). 次に, 栄養素利用効率の変化をみると, 両システ ムともに, 肉牛飼養密度の増加に伴い利用効率は減少す るが, MIX システムと SEP システムによる違いは, 肉牛 飼養密度の影響に比べて小さかった（図 6).

栄養素循環がシステムの栄養素ロスと利用効率に及ぼ す影響を，指数で表したのが図 7 である。影響指数は, SEP システムに対してMIX システムがどの程度増加ある いは減少したかを百分率（\%) で示したもので，その指

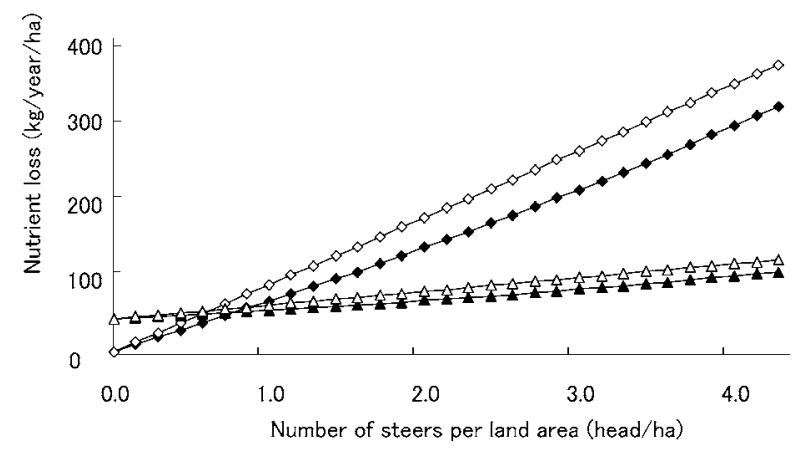

Figure 5 Nutrient loss for nitrogen and phosphorus in MIX and SEP systems as affected by the number of steers per land area. Nitrogen (diamonds) and phosphorus (triangles) in MIX (black) and SEP system (white).

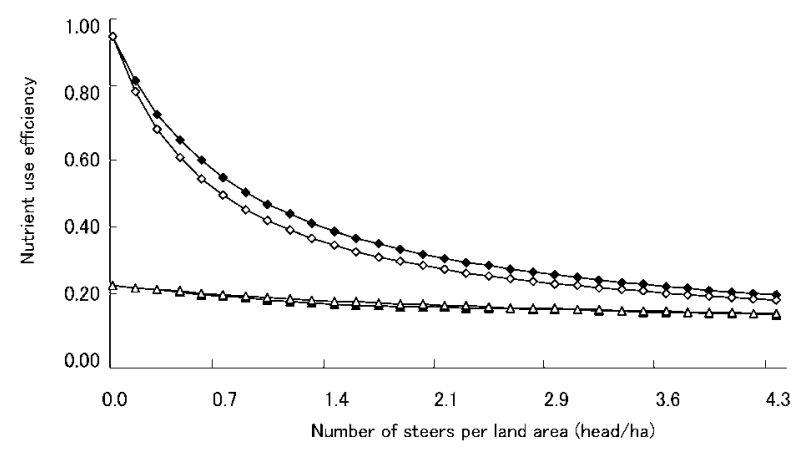

Figure 6 Nutrient use efficiency for nitrogen and phosphorus in MIX and SEP systems as affected by the number of steers per land area. Nitrogen (diamonds) and phosphorus (triangles) in MIX (black) and SEP system (white).
数は, 増加の場合は正, 減少の場合は負となって表れる. 影響指数の正負をみると，ロスでは窒素とリンのどちら も負であり，循環により口ス量が低減されることがわか る. 他方, 利用効率をみると, 影響指数は窒素では正, 逆にリンでは負と，窒素とリンと異なる変化であった。 さらに，内部循環による影響が最も大きくなる肉牛飼養 密度に注目すると, 影響指数は, ロスと利用効率どちら においても，肉牛飼養密度が増加するに伴い，一定の頭 数まで高まり，それ以上では循環の影響が減少すること が示された. したがって，事例とした肉牛肥育一水稲作 複合システムでは, 循環の影響が最大となる肉牛飼養密 度が存在し，その密度は，ロスでは窒素が 1.6 頭/ha, リ ンが 2.6 頭/ha, 利用効率では窒素が 1.6 頭/ha, リンが 1.4 頭/haであることが示された。

\section{3. 循環指標とシステム全体の栄養素収支の関係}

肉牛飼養密度の増加に伴う循環指標の変化は図8 に示 す通りである. 循環指標 ( $\mathrm{Cl}$ ) は肉牛飼養密度の増加に 伴い窒素とリンのどちらも肉牛飼養密度 2.6 頭/ha まで

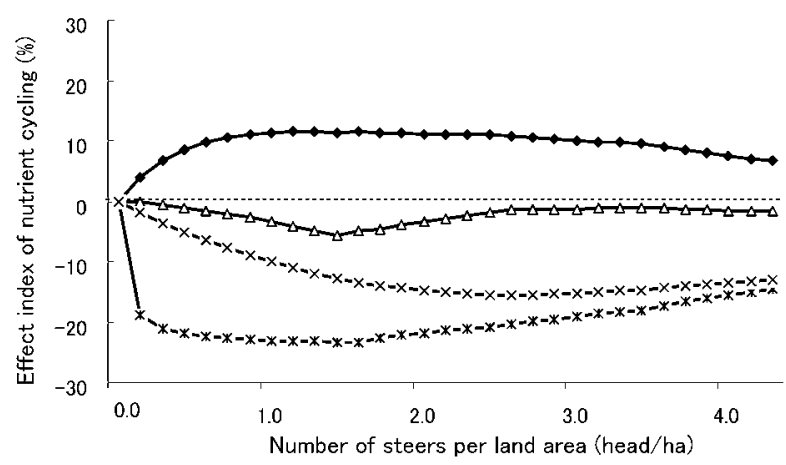

Figure 7 The effect index of nutrient cycling for nutrient use efficiency and losses as affected by the number of steers per land area. Nutrient loss for nitrogen $(*)$ and phosphorus $(X)$ and nutrient use efficiency for nitrogen $(\checkmark)$ and phosphorus $(\triangle)$.

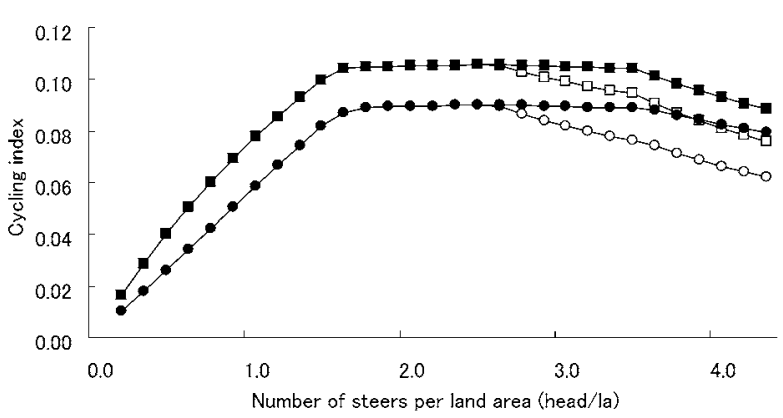

Figure 8 Cycling index for nitrogen and phosphorus as affected by the number of steers per land area. Nitrogen (squares) and phosphorus (circles) in the scenarios when surplus manure was regarded as loss (black) and export (white). 
増加するが, 1.5 頭/ha から 2.6 頭/ha までほとんど増加 せず， 2.6 頭/ha をピークに減少に転じた。このことか ら, 調査農家における肉牛肥育一水稲作複合システムの 栄養素循環の最大値は, 2.6 頭/haであることが示され た。また，堆肥搬出の有無についてみると，堆肥搬出に より, システム内の循環指標 $(\mathrm{Cl})$ は減少した。

システム全体の窒素とリンのロスおよび利用効率と循 環指標との関係を図 9 に示す. まず，システム全体の口 ス量の増加に伴う循環指標の変化について見ると, 余剩 堆肥をシステム内のロスとみなす場合は（窒素口, リン ○), 窒素とリンのロス量が, それぞれ $100 \mathrm{~kg} / \mathrm{ha}, 60 \mathrm{~kg} /$ haになるまで循環指標は増加し，さらにロス量が増加 して, 窒素とリンのロス量がそれぞれ $260 \mathrm{~kg} / \mathrm{ha}, 90 \mathrm{~kg} /$ haを超過するに従い循環指標は減少した. また, 余剩堆 肥を持ち出す場合は（窒素 $\square$, リン○), 循環指標が減少 し始める地点のロス量が余剩堆肥を持ち出さない場合に 比べて少なかったが，これは余剩堆肥の持ち出しにより ロス量の増加が抑えられたためである. 他方, 循環指標 とシステム全体の利用効率の関係を肉牛飼養密度の増加

a) Cycling index and nutrient loss

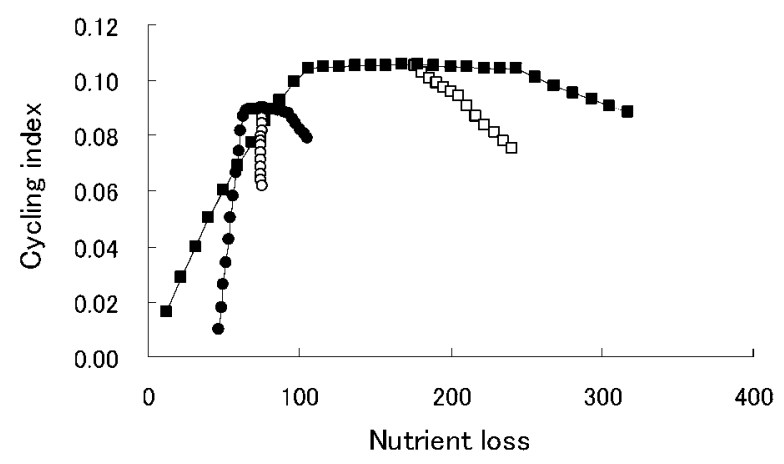

b) Cycling index and nutrient use efficiency

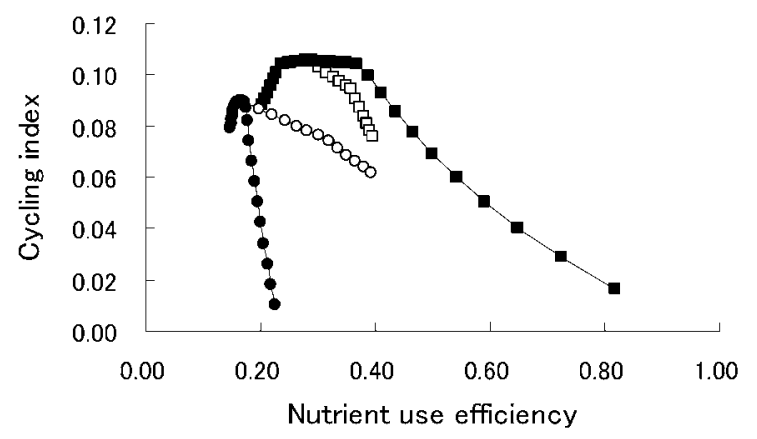

Figure 9 Relationships between cycling indices and nutrient losses (a), and between cycling indices and nutrient use efficiencies (b) for nitrogen and phosphorus in MIX systems. Nitrogen (squares) and phosphorus (circles) in the scenarios when surplus manure was regarded as loss (black) and export (white).
とともに見ていくと，窒素とリンともに最初は利用効率 が高く, 循環指標が低い点から始まり, 飼養密度の増加 とともに, 利用効率は減少し循環指標が高まっていき, 飼養密度が一定値より多くなれば循環指標は減少した。

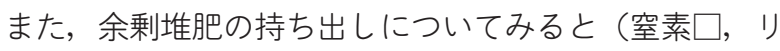
ン○), 余剩堆肥の持ち出しは, 持ち出さない場合より も, 窒素とリンの利用効率を増加させ, 循環指標を減少 させることが示された.

\section{考察}

本研究では，最初に循環系を活用するMIX システムに おいて肉牛飼養密度の増加に伴いシステム全体の栄養素 収支がどのように変化するかを示した（図 2, 図 3, 図 4).その結果，土地あたりのロス量は窒素とリンともに 肉牛飼養密度の増加に伴い増加し, 他方, 家畜あたりの ロス量はどちらも減少することが示された。また，家畜 あたりのロス量の変化は元素間で異なり, 窒素ではリン に比べて大きく減少した。このように元素間の異なりが でたのは，システム内のロスが多い部門が異なることに 由来する.すなわち, 窒素は肉牛肥育部門でロスが多い ことから, 肉牛飼養密度が土地あたりのロス量の増加に 強く影響し, リンでは水稲生産部門でロスが多いことか ら, 肉牛飼養密度が家畜あたりのロス量の減少に強く影 響したと考えられる. 従って, 本事例では, ロス量は窒 素では肉牛飼養密度に, リンでは水田面積に依存するも のと推察された。

肉牛飼養密度の増加に伴う栄養素利用効率の変化は, システムにおける肉牛飼養密度, 肉牛部門之土壤/作物 部門の生産物/搬入比, 堆肥搬出により強く影響を受け ることが示された (図 4). Ondersteijin ら (2003) は, 才 ランダの酪農経営約 240 戸を対象とし, 酪農システムの 窒素とリン酸の余剩量（搬入量一搬出量）に影響を及ぼ す要因を統計解析により検討した。.その結果, システム における窒素収支とリン酸収支に影響を及ぼす要因とし て, 土地または家畜体あたりの乳生産量, 牛群に占める 育成牛の割合, 草地への化学肥料散布量, 農家への正味 堆肥搬入量 (搬入量一搬出量), 濃厚飼料中の含有量, 標 準値以上の飼料購入の影響が指摘されている. 彼らの研 究において指摘された要因は, 酪農システムの結果であ り, 本研究で対象とした肉牛肥育一水稲作システムとは 異なるシステムであるが, 本研究で利用効率について指 摘した要因と類似点が認められる。すなわち, 家畜部門 の生産物/搬入比に関わるものとして, 家畜体あたりの 乳生産量, 牛群に占好育成牛の割合, 濃厚飼料中の成 分量, 標準量を超過した飼料購入量が挙げられ, 土壤/作 物部門の生産物/搬入比に関わるものとして草地への化 学肥料散布量が, 家畜飼養密度に関わるものとして土地 あたりの乳生産量が，堆肥搬出の有無に関わるものとし て農家への正味堆肥搬入量が挙げられるからである. 
従って, 本研究で指摘したシステムの栄養素利用効率に 影響を及ぼす要因は，本事例に留まらない可能性が考え られた。

次に, 栄養素循環の有無によりシステム全体の栄養素 収支がどのように変化するかを, 循環が成立するシステ ム (MIX システム) と循環が成立しないシステム（SEP システム）との比較により明らかにすることを試みた。

その結果, 内部循環がシステム全体の栄養素ロスに及ぼ す影響は，窒素とリンのどちらも負であり，内部循環は 栄養素ロスの低減につながることが示された（図 5). 他 方, 内部循環が栄養素利用効率に及ぼす影響は, 窒素と リンのよ゙ちらも, 肉牛飼養密度に伴う利用効率の減少よ りも小さかった（図6).このことは, 言い換えれば, 利 用効率に大きな影響を及ぼす要因として指摘した，家畜 部門と土壤/作物部門の生産物/搬入比, 堆肥般出の影響 より小さいものであると言える. したがって, 本事例に おいては，栄養素利用効率の増減に影響を及ぼす要因と して内部循環は他の要因より影響が小さいものと推察さ れた。また, 内部循環の影響を影響指数から見ると, 利 用効率への影響は窒素では正, リンでは負であり, 内部 循環はリンではシステム全体の利用効率の増加には繋が らなかった（図 7)。このように窒素とリンの間で影響が 異なるのは, 循環の成立により, 本来であればシステム から般出される窒素とリンが, システム内部で利用され たことによるものである. 具体的には, 調査農家では, 肉牛飼養に利用されなかった作物副産物の米妨籾殻 がシステム外に搬出されるが, 肉牛飼養密度の増加に伴 い, これらの搬出項目がシステム内で利用されることに なるため搬出量が減少し, さらに, 米めかはリン含量が 多いため, 結果的に搬出量の減少が窒素よりリンで大き くなったためである.これまで, システムにおける栄養 素循環の影響は, システムの栄養素利用効率の増加に繋 がると考えられてきたが，本シミュレーションの結果か ら，必ずしもそうならないことが示されたことは興味深 いと考えられる.

肉牛飼養密度の増加は, 副産物と堆肥利用可能量を増 加させるが，一定の飼養密度を超過すると，システム全 体のロスの増加や利用効率の減少につながる. 本研究で は, 肉牛飼養密度の増加に伴う循環指標の変化を検討 し，その結果，事例農家においては肉牛飼養密度が 2.6 頭/haで，システム内の栄養素循環が最大となることを 明らかにした。家畜飼養密度と内部循環の関係性の検討 は, 他にも佐藤ら（2007）が行っている. 彼らは既報の デー夕をもとに, システム内の窒素循環を, 窒素循環率 （システムへの搬入窒素量に対する自給飼料窒素量の比 率）で表し，様々なシステム事例について比較した。そ の結果, 彼らは単位面積当たりの牛飼養頭数が高くなる と, 窒素循環率が減少することを指摘した. 彼らの報告 では窒素循環率の減少のみが指摘されているが，肉牛飼
養密度の非常に低い状況では家畜一作物間の循環量は少 なくなると考えられるため, 実際には本事例で示したよ うに, 肉牛飼養密度の増加とともに内部循環は高まり, 一定の頭数以上において内部循環が減少に転じることが 妥当と考えられる.

栄養素循環がシステム全体の栄養素収支から判断でき るか否かは, 簡易に栄養素循環を評価する手法を構築す るうえで重要である. 本事例において, 栄養素循環 $(\mathrm{Cl})$ とシステム全体の栄養素ロスおよび利用効率の関係を示 した結果（図 9)，窒素とリンともに，ロス量と利用効率 が一定範囲において, 循環が最大となることが示唆され た。このことは，システムの内部循環が一定の家畜密度 において最大となることに由来すると考えられる。しか しながら, 肉牛飼養密度の増加に伴う変化で見た場合, システム全体の栄養素収支と内部循環には同調した変化 が認められなかった．このことは，システム全体の栄養 素収支から内部循環を推察することが困難であることを 示すものと考えられる (図 9). Nielsen と Kristensen （2005）は，デンマークの酪農家と養豚農家における有機 農家と慣行農家の窒素収支とリン収支を検討し, 本研究 と同様に，農家全体のシステムの利用効率からではシス テム内部の栄養素フローを解釈することが困難であるこ とを考察している. 本研究の結果は彼らの指摘と一致す るものであり，システム内部の栄養素フローを検討する には，内部のフロ一量を定量化することが必要と考えら れた.

本研究では，事例デー夕を用い，肉牛飼養密度を軸亡 した栄養素のシステム全体の収支および内部循環の変化 を予測し，システム全体の収支に影響を及ぼす要因，お よび内部循環がシステム全体の栄養素収支に及ぼす影響 や関係性を示した．本研究におけるシミュレーションの 結果は, コンピュータの計算により示された値であり, その意味で具体的な予測の域を出ないものである。しか しながら, 農家レベルの生産システムという大きなス ケールを研究対象とする場合, 実験的手法により検討を 進めることは, 実験反復や局所管理の問題, さらには労 力上の問題があるため, 限界があるものと予想される. そのような場合, シミュレーションによる研究は, 様々 な状況について予測できることから，農家レベルの生産 システムにおける栄養素利用を検討する上で有用な方法 と考えられた。

\section{謝辞}

本研究の発表には, 第 12 回 AAAP大会 (韓国・プサン) 参加若手研究者への参加費助成が行われた。 また, 本研 究の一部は科学研究費補助金（基盤 B No. 17380161）お よび特別研究員奨励費（田端祐介No. 19・5990）により 行われたものである. 


\section{文献}

Finn JT. 1976. Measures of ecosystem structure and function derived from analysis of flows. Journal of Theoretical Biology 56, 363-380.

Finn JT. 1980. Flow analysis of models of the Hubbard Brook ecosystem. Ecology 61, 562-571.

Finn JT. 1983. Cycling index. Nature 304, 397.

Nielsen AH, Kristensen IS. 2005. Nitrogen and phosphorus surpluses on Danish dairy and pig farms in relation to farm characteristics. Livestock Production Science 96, 97-107.

Ondersteijin CJM, Beldman ACG, Daatselaar CHG, Giesen GWJ, Huirne RBM. 2003. Farm structure or farm management: effective ways to reduce nutrient surpluses on dairy farms and their financial impacts. Livestock Production Science
84, 171-181.

押田敏雄，柿市徳英，羽賀清典. 2002. 畜産と環境. 畜産環境保 全論. pp. 1-18. 養賢堂, 東京.

佐藤寿樹, 藤田 泉, 宮本 誠. 2007. 物質循環からみる耕畜連 携営農集団の持続性に関する課題一広島県庄原市一木営農 集団の窒素循環事例から一。 農村研究 104, 42-53.

田端祐介，北川政幸，稲村達也，石田定顕，広岡博之. 2005. 肉 牛肥育一水稲複合生産システムにおける窒素利用と窒素循 環. 日本畜産学会報 76, 321-330.

田端祐介，北川政幸，稲村達也，石田定顕，広岡博之. 2006a。 肉牛肥育一水稲複合生産システムにおけるリン利用とリン 循環. 日本畜産学会報 77, 279-288.

田端祐介, 石田定顕, 稲村達也, 野田昌伸, 広岡博之. 2006b. 和牛繁殖一水稲作複合システムにおける窒素とリンの利用 と循環. 肉用牛研究会報 82, 4-12.

\title{
The relationship between nutrient cycling and farm level nutrient balances in the mixed farming systems for beef fattening and rice production
}

\author{
Yusuke TABATA, Kazato OISHI, Hajime KUMAGAI and Hiroyuki HIROOKA
}

Graduate school of agriculture, Kyoto University, Sakyo, Kyoto 606-8502, Japan

Corresponding : Yusuke TABATA (fax : +81 (0) 75-753-6365, e-mail : ytabata@kais.kyoto-u.ac.jp)

The objectives of present study were to investigate the effects of nutrient cycling and relationship between nutrient cycling and nutrient balances in the mixed farming systems for beef fattening and rice production. Nutrient flow models for nitrogen and phosphorus in a farming system were developed from data of a surveyed farm. The models simulated nutrient balances and nutrient cycling with change of animal intensification represented as the number of steers per area. The results indicated that nutrient use efficiencies (exports/imports) were more affected by animal intensification, the ratio of products to import for beef fattening and rice production, and exports of manure than by nutrient cycling in the systems. The nutrient cycling decreased nutrient losses (imports minus exports). However, the nutrient cycling increased nitrogen use efficiency but decreased phosphorus use efficiency. The relationship between nutrient balances and nutrient cycling (cycling index) was not found clearly. It was concluded that the simulation approach was a useful tool to analyze nutrient balances and cycling in mixed crop-livestock farming systems.

Nihon Chikusan Gakkaiho 79 (1), 79-88, 2008

Key words : beef fattening, farm level, mixed crop-livestock farming system, nutrient cycling, rice production. 